\title{
The Effect of Van Hiele Learning Model Based Geogebra on Students' Spatial Ability
}

\author{
Widyah Noviana ${ }^{1}$,Windia Hadi ${ }^{2}$ \\ ${ }^{1}$ Universitas Pamulang, Jl. Surya Kencana No.1 Pamulang, Tangerang Selatan, Indonesia \\ dosen02314@unpam.ac.id \\ ${ }^{2}$ Universitas Muhammadiyah Prof. DR. HAMKA, Jalan Tanah Merdeka, DKI Jakarta, Indonesia. \\ windia.hadi@uhamka.ac.id \\ *Corresponding author: windia.hadi@uhamka.ac.id
}

\begin{abstract}
This research aimed to discover the effect of Model Van Hiele Based Geogebra on Students' Spatial Ability. The population of this research is all Students at University Muhammadiyah of Prof. DR. HAMKA. The sample in this research are students' of the second semester of the mathematics education study program. This research was conducted online due to COVID-19. The research method used is quasi-experimental. Data collection used a mathematical spatial ability test instrument. The data analysis technique used a t-test. The result showed that students' mathematical spatial ability treated with the Model Van Hiele Based Geogebra was not higher than whose mathematical spatial ability of students' treated with the conventional models. That is due to several factors, namely internal and external factors.
\end{abstract}

Keywords: Geogebra, Spasial Ability, Model Van Hiele.

\section{INTRODUCTION}

Geometry is one of the main concepts students learn, and a branch of mathematics taught before higher education and then has an essential role in mathematics [1], [2]. The explanation for this is that students already know geometric ideas as previously. The concepts of geometry have been recognized by students informally before they sit in school through objects concrete around them, which contains geometric images/ideas. These concepts include line concepts, flat shapes, and space shapes [3]. Geometry not only improves the cognitive capacity of the students but also helps the students in the training memory, namely from concrete objects to abstract so that learners have belief in mathematical competence, can communicate, become great problem solvers, and have mathematical and to develop logical thinking skills, develop spatial intuition about the real world, provide more knowledge about geometry, and teach read and interpret mathematical arguments. [4], [5]. May you learn geometry to help the students understand their ability to think and solve everyday problems, exercise their skill essential logical reasoning skill, and prepare for further studies and acquisition later. Technical Job and Van Hiele stated that one's ability to work in geometry is affected by the right geometry studying experiences [6], [7]. Also, geometry helps students to connect geometric structures with other mathematical submissions they encounter in their environment and solve problems they face in their daily lives through the relationships they build [8]. The lecturer must know the development of his student thinking [9] because his knowledge is different from the students. Students do not understand the lecturer's 
explanation, so that the teacher needs to identify the student's geometry level.

The facts on the ground show that the mastery of geometric concepts that students have is still low, results in students' learning the geometry of students is still low, so that students experience difficulty studying geometry. The short mastery of geometric concepts is possible because of understanding concepts and abilities in solving geometric problems that are still weak. Apart from that, another probable cause is the learning process given by educators, not following the skills possessed by each student because students have different abilities. The difficulty of understanding geometry occurs because they have a problem thinking of abstract forms, analyzing the properties of observed geometric objects, and presenting geometric objects in images. Moreover, students also feel less interested in learning mathematics[1]-[3]. The previous observation [5] stated that the three-dimensional figure is the most challenging mathematics learning material. It is because the threedimensional model is an abstract concept. Also, there are several problems occur, namely (a) the students' skills in drawing and using the tools to draw threedimensional figure is still low; (b) the students' ability to understand the mathematical concepts is still unsatisfactory; (c) some students only rely on memorization without understanding the idea so that they make mistakes on finishing the problem; and (d) the prerequisite material includes straight lines, angles, the area of the two-dimensional figure, trigonometry and the requisites for Pythagoras theorem application have not been mastered by some students [10]. For students' geometry learning difficulties, it is recommended to apply the theory of van Hiele. According to van Hiele's view, the students work by the stages of students' thinking, so students are increasingly interested in learning [11].

Also, students' difficulty in learning geometry is caused by the lack of spatial ability caused by internal factors having trouble concentrating and lacking the ability to express their ideas. Besides that, students' lack of spatial knowledge can also be caused by external factors, including their residential environments and formal education [12], [13]. By definition, the spatial ability is perceptual and cognitive abilities that make someone see the spatial relationship (Carter, 2010). According to Linn \& Pitersen (1985), spatial ability is a mental process in preserving, recalling, generating, transforming, and communicating solid. Maier (1996) said that spatial ability is an abstract concept that consist of five elements, which are (1) Spatial Perception, the ability to perceive an object both vertically and horizontally; (2) Spatial Visualisation, the ability to visualize the motion of a solid; (3) Mental Rotation, the ability to determine the position of an object after rotation by a specific direction; (4) Spatial Relation, the ability to understand the elements of an item and the relationship between a component to the other part; and (5) Spatial Orientation, the ability to maintain our body orientation to the surrounding environment both physically and mentally. Spatial ability needs to be improved in learning mathematics, especially in concrete platonic topics. Spatial ability is required in learning geometry. It is supported by the study conducted by Tessema (2018), which stated that spatial ability gives a significant effect to the geometric ability of primary students in Ethiopia and contributes as much as $29.90 \%$ of all variables that determine the geometric ability. However, generally, it was not a concern for the teacher when giving a lesson at school as the focus is to provide the information to be memorized (Syahputra, 2011). Studying geometry takes the ability to represent an abstract concept in two / three-dimensional visual form and make changes to a geometric shape called spatial ability. Students who have high spatial abilities will easily understand geometry problems because it can detect relationships and changes in geometric shapes [14].

Van de Walle's research (2001), students have not been able to state the properties of a form or clear geometric ideas. The results showed that students looked at the room just as something that is around them. In line with Syahputra \& Fauzi's research (2017), students' problem has difficulty visualizing for geometry problem problems. In other words, students have not been able to attract relationships into concepts in geometry. Do not rule out; this problem has carried over the college level. That is supported by research by Ayuningrum, Kusuma, \& Rahmawati (2019); difficulties in learning geometry include difficulties in imagining or imagine the relationship of problems encountered with the concept of geometry. Should according to (Crowley 1987), the idea of geometry is seen more as a unit, but students have not been able to analyze in its parts. Referring to van Hieles' theory, de Villiers (2010) suggests the main reason. Failure geometry curriculum was caused by the fact that the curriculum was presented at a level higher cognitive learners, in this case, our students. In other words, they cannot understand the educator, and the educator knows why they can't understand. Problems related to the level of awareness given in the material with students' cognitive abilities, this is what then the background to focus this research. In this study, the specific problem is specific to the cognitive style [15].

Based on the explanation above, innovation is required in the learning process. One of the learning processes is to apply a learning model that is specifically designed for learning geometry; thus, students can be mentally involved in the learning process to improve their spatial ability. Van Hiele's learning model is a learning model based on Van Hiele's levels of thinking. In Van Hiele's learning model, teachers have to observe 
students' readiness in receiving the lesson, such as the students' attitude, enthusiasm, and physiology [2]. Van Hiele's Geometry learning model requires student participation in routine activities and allows students to explore some related characteristics with geometry to achieve specific goals (Gutierrez in Erdogan, 2009: 183). The stages of learning in the geometry learning model by van Hiele (Crowley, 1987: 5) as follows: Information, Directed Orientation, Eksplisitasi (Eksplicitation), Free Orientation (Free Orientation), and Integration (Integration). The learning stages in van Hiele's geometry learning model enable students to have a strong desire, awareness, and dedication to themselves students to study and participate in learning geometry. At the information stage, students invited to discuss to explore their initial abilities regarding a concept will be reviewed so that at this stage, students are expected to have a desire to study geometry. Students carry out activities observations in the integrated orientation stage to understand a concept so that it is expected at this stage; students have the confidence to solve the problem given. At the stage Eksplisitasi, students begin to express the geometric concepts learned orally in their own words, thus enabling them to communicate ideas and their reasons. The free orientation stage allows students to have persistence in solving more complicated geometric problems. The integration Stage will allow students to monitor and reflect the geometric thought process [16].

Therefore, teachers must provide learning experiences appropriate to students' geometrical thinking to lead students to think maturely facing the process. Also, the teacher can form a learning experience by provided such a method or by use instructional media [17]. In this case, geometric requires media to facilitate learning as well as a tool, namely GeoGebra. Because of the geometry and learning materials not adjusted, it will cause a lack of success in learning mathematics [5]. Geometry material will be more exciting and meaningful if presented using instructional media that can visualize abstract objects. One of the visual media used as a learning medium is Geogebra [18]. The skills in using learning media, namely GeoGebra, to complement van Hiele's theory are expected to provide information about students' difficulties. GeoGebra is a dynamic mathematics software used as a tool in learning mathematics, precisely measuring students' geometrical spatial abilities based on the van Hiele model [5]. However, this software was developed for the practical mathematics teaching and learning process Schools use at least three uses, namely mathematics learning media, mathematics teaching material, and solving math problems [19].

\section{METHOD}

This research is quantitative and quasi-experimental because the researcher can't control or manipulate all the relevant variables, except for some of the variables under study. This study's population is the target population of all colleges of the Teaching and Education Faculty in East Jakarta; 5 universities have Teaching and Education Faculties, including Universities and Colleges. One of the faculty of teacher training and education in East Jakarta was chosen, namely Prof. Muhammadiyah University. Dr. Hamka, so that the affordable population is all students of Prof. Muhammadiyah University. Dr. Hamka. The research sampling technique was obtained through purposive sampling and random sampling techniques. The research sample was obtained through a random sampling technique of 60 students divided into 30 students in the experimental class and 30 students in the control class. The instrument used in this study was a mathematical spatial ability test instrument-the data analysis technique used t-test with the help of SPSS 22.

\section{RESULT AND DISCUSSION}

\subsection{Descriptive Analysis of Spatial Mathematical Ability Data}

The students' mathematical spatial ability in the group treated with the Geogebra-based Van Hiele Model and the descriptive conventional learning group are presented in Table 1.

Table 1. Descriptive Statistics of Spatial Mathematical Abilities

\begin{tabular}{|c|c|c|c|c|c|c|c|c|c|c|}
\hline \multirow{2}{*}{ Nilai } & \multicolumn{6}{|c|}{ Model Van Hiele Berbasis Geogebra } & \multicolumn{5}{|c|}{ Pembelajaran Konvensional } \\
\cline { 2 - 10 } & $\mathrm{N}$ & Min & Maks & $\bar{x}$ & SD & $\mathrm{N}$ & Min & Maks & $\bar{x}$ & SD \\
\hline \multirow{2}{*}{ Tes } & 30 & 5 & 15 & 9,67 & 2,5 & 30 & 6 & 14 & 9,63 & 1,81 \\
\hline
\end{tabular}


Based on Table 1, the results of students' mathematical spatial abilities who were treated with the Van Hiele Model Based on Geogebra with a sample size of 30 students obtained a minimum score of 5 , a maximum score of 15 , an average score of 9.67 , and a standard deviation of 2.5, while the results of the ability students who were given conventional learning treatment with a sample size of 30 students obtained a minimum score of 6 , a maximum score of 14 , an average score of 9.63 and a standard deviation of 1.81 .

\subsection{Prerequisite Test of Mathematical Spatial Ability Data}

Furthermore, the data analysis prerequisite test was carried out. Based on the normality test for the class treated with the Geogebra-based Van Hiele Model, it was obtained $0.533>0.05$, and the normality test for the grade treated with conventional learning was 0.129> 0.05 . That means that the students' mathematical spatial abilities treated with the Geogebra-based Van Hiele Model and traditional education are typically distributed. While the homogeneity test in the class treated with the Van Hiele Model Based on Geogebra and conventional learning was $0.063>0.05$. That means that students' mathematical spatial abilities who are treated with the Van Hiele Model Based on Geogebra and traditional education have the same variance. The conclusion is that the Van Hiele Model classes based on Geogebra and conventional learning are typically distributed and homogeneous.

\subsection{Hypothesis Testing of Spatial Mathematical Ability Data}

After the prerequisite test is met, then the hypothesis testing is carried out using the t-test. The results of calculations with the t-test regarding spatial ability were carried out using SPSS 22, presented in table 2 as follows:

Table 2. Hasil T-Test of Mathematical Spatial Ability Data

\begin{tabular}{|c|c|c|c|}
\hline Model & \multicolumn{3}{|c|}{ t-test for Equality of Means } \\
\cline { 2 - 4 } Pembelajaran & T & Df & Sig. (2-tailed) \\
\hline $\begin{array}{c}\text { Model Van Hiele Berbasis } \\
\text { Geogebra } \times \text { Konvensional }\end{array}$ & 0.59 & 58 & 0.953 \\
\hline
\end{tabular}

Based on table 2 above, it is obtained 0.953>0.05 at the significance level $\alpha=0.05$. That means that students who received the Geogebra-based Van Hiele Model treatment's mathematical spatial abilities were not higher than students who received conventional treatment. That can be seen from the average score of students treated with the Geogebra-based Van Hiele Model of 9.67, while the average score of students who were given conventional treatment was 9.63. That shows that the scores of the two are not much different. From the results of observations experiments carried out by researchers through distance learning (online) due to the Covid-19 pandemic, the results show that there are many obstacles in the experimental process on the application of the Geogebra-based Van Hiele Model faced by students, namely quotas, networks and a lack of understanding of students in applying. GeoGebra software with online learning affects students' spatial ability in studying problems in Euclid's geometry. That is supported by research [20] that there are difficulties faced by mathematics education students, namely 1) technical difficulties, including internet signal difficulties, internet quota limitations, and supporting devices, 2) student adaptation difficulties, which include home conditions. Conducive, not used to online lectures, more online assignments, and difficulty managing time.
Another fact if analyzed from the results of student answers. Each student has a different level of geometrical thinking; this is supported by research [21] that every student has a different level of geometric thinking, both male and female students. That is also supported by research [22] that a person or student's intelligence is one of the factors that can determine the success or failure of learning mathematics, especially geometry.

\section{CONCLUSION}

Based on the results of data analysis and discussion of research results, it can be concluded that the mathematical spatial ability of students who received the Geogebra-based Van Hiele Model treatment was not higher than students who received conventional treatment.

\section{ACKNOWLEDGMENTS}

The researcher says to thank the Directorate of Research and Community Service, Directorate General of Research and Development Strengthening Ministry of Research, Technology and Higher Education following Research Contract Number: 0180/D5/ 
KP/LPPM/UNPAM/ IV/2020 jo and also to students who participated and assisted the data collection process in this study.

\section{REFERENCES}

[1] S. Wiska, E. Musdi, and Y. Yerizon, "Teacher and students response to learning devices based on van hiele theory," Journal of Physics: Conference Series, vol. 1554, no. 1, 2020, doi: 10.1088/1742-6596/1554/1/012002.

[2] I. G. N. Pujawan, I. P. P. Suryawan, and D. A. A. Prabawati, "The effect of van hiele learning model on students' spatial abilities," International Journal of Instruction, vol. 13, no. 3, pp. 461474, 2020, doi: 10.29333/iji.2020.13332a.

[3] E. N. Z. Rinaldi, Supratman, and R. Hermanto, "Proses Berpikir Peserta Didik Ditinjau Dari Kemampuan Spasial Berdasarkan Level Berpikir Van," Journal of Authentic Research on Mathematics Education (JARME), vol. 1, no. 1, pp. 38-45, 2019.

[4] A. M. Ramlan, "The Effect of Van Hiele Learning Model Toward Geometric Reasoning Ability Based on Self-Efficacy of Senior High School Students," Journal of Mathematics Education, vol. 1, no. 2, pp. 63-72, 2016.

[5] A. M. Ramlan, E. Cahyono, and F. Hali, "Geometric Reasoning Ability Based on Van Hiele Theory by Geogebra Software," vol. 1, no. January, pp. 69-74, 2020, doi: 10.31327/icusnadri.v1i0.1141.

[6] E. Yudianto, Sunardi, T. Sugiarti, Susanto, Suharto, and D. Trapsilasiwi, "The identification of van Hiele level students on the topic of space analytic geometry," Journal of Physics: Conference Series, vol. 983, no. 1, 2018, doi: 10.1088/1742-6596/983/1/012078.

[7] A. Jupri, "Using the Van Hiele theory to analyze primary school teachers' written work on geometrical proof problems," Journal of Physics: Conference Series, vol. 1013, no. 1, 2018, doi: 10.1088/1742-6596/1013/1/012117.

[8] F. Karapınar and O. Alp İlhan, “An Investigation of 8th Grade Students' Knowledge on Geometrical Objects in Terms of Van Heile Levels of Understanding Geometry," American Journal of Educational Research, vol. 6, no. 2, pp. 96-103, 2018, doi: 10.12691/education-6-2-1.

[9] E. Sudihartinih and Wahyudin, "The van hiele levels of geometric of students in first semester reviewed from gender," Journal of Physics: Conference Series, vol. 1280, no. 4, 2019, doi: 10.1088/1742-6596/1280/4/042034.

[10] B. R. Hidayat, B. Sugiarto, and G. Pramesti, "Analisis Kesalahan Siswa Dalam Menyelesaikan
Soal Pada Materi Ruang Dimensi Tiga Ditinjau Dari Gaya Kognitif Siswa ((Penelitian dilakukan di SMA Negeri 7 Surakarta Kelas X Tahun Ajaran 2011/2012)," Jurnal Pendidikan Matematika Solusi, vol. 1, no. 1, pp. 39-46, 2013.

[11] B. Junedi, "Penerapan Teori Belajar Van Hiele Pada Materi Geometri Di Kelas VIII," MES: Journal of Mathematics Education and Science, vol. 3, no. 1, pp. 1-7, 2017, doi: 10.30743/mes.v3i1.213.

[12] L. E. Pradika and C. E. Murwaningtyas, "Analisis Kesalahan Siswa Kelas Viii I Smp N 1 Karanganyar Dalam Mengerjakan Soal Pada Pokok Bahasan Bangun Ruang Sisi Datar Serta Upaya Remediasinya Dengan Media Bantu Program Cabri 3D," no. November, pp. 978-979, 2012.

[13] I. Permatasari, I. Pramudya, and T. A. Kusmayadi, "Spatial ability of slow learners based on Hubert Maier theory," Journal of Physics: Conference Series, vol. 983, no. 1, 2018, doi: 10.1088/1742-6596/983/1/012095.

[14] N. Faradhila, S. Imam, and K. Yemi, "Eksperimentasi model pembelajaran missouri mathematics project (MMP) pada materi pokok luas permukaan serta volume prisma dan limas ditinjau dari kemampuan spasial siswa kelas VIII Semester Genap SMP Negeri 2 Kartasura Tahun Ajaran 2011/2012," Jurnal Pendidikan Matematika Solusi UNS, vol. 1, no. 1, pp. 67-74, 2013.

[15] N. Muhassanah and F. Mulyatna, "Analisis Tingkat Berpikir Geometris Menurut Van Hiele pada Mata Kuliah Geometri Analitik Ditinjau dari Gaya Kognitif," vol. 2682, no. 2, pp. 233-244, 2020.

[16] T. Nopriana, "FIBONACCI Jurnal Pendidikan Matematika \& Matematika," FIBONACCI Jurnal Pendidikan Matematika \& Matematika, vol. 1, no. 2, pp. 80-94, 2015.

[17] S. Andini, L. Fitriana, and Budiyono, "Elementary school students visual spatial comprehension based on van Hiele Theory: The case in Madiun, East Java, Indonesia," Journal of Physics: Conference Series, vol. 983, no. 1, 2018, doi: 10.1088/1742-6596/983/1/012097.

[18] Y. Ariani, R. Johar, and M. Marwan, "Penggunaan Software Cabri 3D Untuk Meningkatkan Kemampuan Spasial Siswa Sekolah Menengah Pertama," Jurnal Peluang, vol. 7, no. 2, pp. 11-21, 2019, doi: 10.24815/jp.v7i2.13695.

[19] I. M. Nur, "Pemanfaatan Program Geogebra dalam Pembelajaran Matematika," Jurnal Matematika dan Pendidikan Matematika, vol. 5, 
no. 1, pp. 10-19, 2016, doi: 10.1038/oncsis.2016.1.

[20] M. F. Annur and H. Hermansyah, "Analisis Kesulitan Mahasiswa Pendidikan Matematika dalam Pembelajaran Daring Pada Masa Pandemi Covid-19," Paedagoria: Jurnal Kajian, Penelitian dan Pengembangan Kependidikan, vol. 11, no. 2, pp. 195-201, 2020.

[21] L. A. D. Musa, "Level Berpikir Geometri Menurut Teori Van Hiele Berdasarkan
Kemampuan Geometri dan Perbedaan Gender Siswa Kelas VII SMPN 8 Pare-Pare," AlKhwarizmi: Jurnal Pendidikan Matematika dan Ilmu Pengetahuan Alam, vol. 4, no. 2, pp. 103116, 2018, doi: 10.24256/jpmipa.v4i2.255.

[22] M. Imamuddin and I. Isnaniah, "Profil Kemampuan Spasial Mahasiswa Camper Dalam Merekonstruksi Irisan Prisma Ditinjau Dari Perbedaan Gender," MaPan, vol. 6, no. 1, pp. 3139, 2018, doi: 10.24252/mapan.2018v6n1a4. 